\title{
Selected Prehistoric Caddo Sites in the Upper Sabine River Basin of Northeast Texas
}

Timothy K. Perttula

Heritage Research Center, Stephen F. Austin State University

LeeAnna Schniebs

Follow this and additional works at: https://scholarworks.sfasu.edu/ita

Part of the American Material Culture Commons, Archaeological Anthropology Commons, Environmental Studies Commons, Other American Studies Commons, Other Arts and Humanities Commons, Other History of Art, Architecture, and Archaeology Commons, and the United States History Commons

Tell us how this article helped you.

This Article is brought to you for free and open access by the Center for Regional Heritage Research at SFA ScholarWorks. It has been accepted for inclusion in Index of Texas Archaeology: Open Access Gray Literature from the Lone Star State by an authorized editor of SFA ScholarWorks. For more information, please contact cdsscholarworks@sfasu.edu. 
Selected Prehistoric Caddo Sites in the Upper Sabine River Basin of Northeast

Texas

Creative Commons License

(c) (i) (8)

This work is licensed under a Creative Commons Attribution-NonCommercial 4.0 International License 


\title{
Selected Prehistoric Caddo Sites in the Upper Sabine River Basin of Northeast Texas
}

\author{
Timothy K. Perttula, with contributions by LeeAnna Schniebs
}

\section{INTRODUCTION}

Some years ago, I commented that the upper Sabine River basin in Northeast Texas had "a highly significant and diverse archaeological record, one that has intrigued professional and avocational archaeologists alike for at least 75 years" (Perttula 1995:v). At the same time, I noted that "we still know very little about the prehistoric and early historic Caddoan groups who lived in the basin, and unfortunately it has been a number of years since dedicated archaeologists, professional or avocational, turned their attention to this region" (Perttula 1995:v).

In this article, I present information on five different prehistoric Caddo sites in the upper Sabine River basin, specifically in Smith and Wood counties, Texas (Figure 1). What these five sites share besides the fact that they are prehistoric Caddo sites is that the findings from the archaeological work completed at them has not previously been made available to, or shared with, the archaeological community, despite the work having been done more than 20-30 years ago (sporadically between 1977 and 1986). Each of the five sites is important in its own right as a place where the prehistoric heritage of the Caddo peoples has been preserved, and together they help illuminate the native history of the Caddo in the upper Sabine River basin of their traditional homelands.

\section{THE SITES}

\section{SM169}

This site was located during a 1986 reconnaissance survey of the proposed Waters Bluff Reservoir along the Sabine River (Perttula 1986). It is situated on two large alluvial knolls overlooking the Sabine River and Mill Creek floodplains (Figure 2). An old channel of the Sabine River, called the "Big Eddy," lies about $210 \mathrm{~m}$ north of 41SM169. The site is estimated, based on shovel testing (all six shovel tests contained prehistoric artifacts, and ceramic sherds were found in ST 3, 5, and 6 [Perttula 1986]), and a subsequent surface collection, to cover a 14,400 $\mathrm{m}^{2}$ area (3.6 acres).

There are two distinct midden deposits (Midden A and B) on the crest of the alluvial knolls at 41SM169 (see Figure 2), both at least 10-15 $\mathrm{m}$ in diameter and a maximum of $55 \mathrm{~cm}$ in thickness as determined by shovel testing. The surface collection of artifacts from 41SM169 (Table 1) derives from Midden A at the eastern edge of the landform.

The grog-, bone-, bone-grog, and grog-hematite-bone-tempered sherds from 41SM169 are primarily from the undecorated portions of ceramic vessels or from plain vessels; the plain to decorated sherd ratio is 7.50, suggesting the Caddo occupation here predates ca. A.D. 1200. One of the decorated sherds is from a bottle that has curvilinear engraved lines on the vessel body. One rim from 41SM169 has rows of tool punctations, a body sherd has opposed incised lines, and another body sherd has rows of tool punctations.

The bifacial tool fragment, possibly from the blade of an arrow point or a thin bifacial knive, is made from a local quartzite. The core is also on the local coarse-grained quartzite. Among the lithic debris, quartzite $(n=6)$ and petrified wood $(n=2)$ are well represented, along with a local brown chert $(\mathrm{n}=1)$; all these materials are likely available in local gravel sources and $56 \%$ have cortical remnants. Non-local lithic debris is also present in the chipped stone, including a dark brown chert $(\mathrm{n}=1)$, a gray chert $(n=1)$, and a dark gray chert $(n=1)$.

\section{SM170}

41SM170 was also recorded during the archaeological reconnaissance of the proposed Waters Bluff 


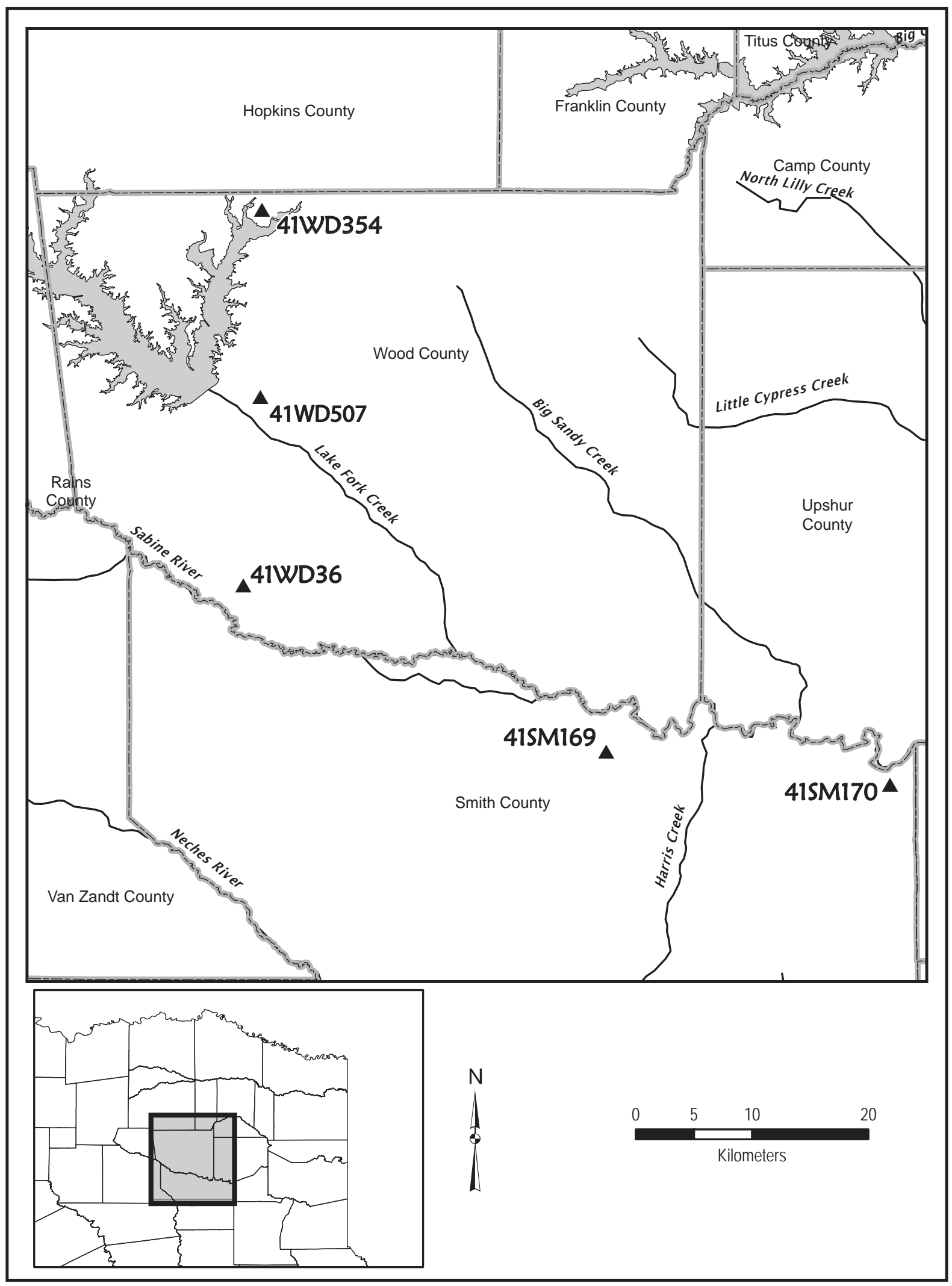

Figure 1. Locations of sites discussed in the text from the upper Sabine River basin in Northeast Texas. Map prepared by Sandra Hannum. 


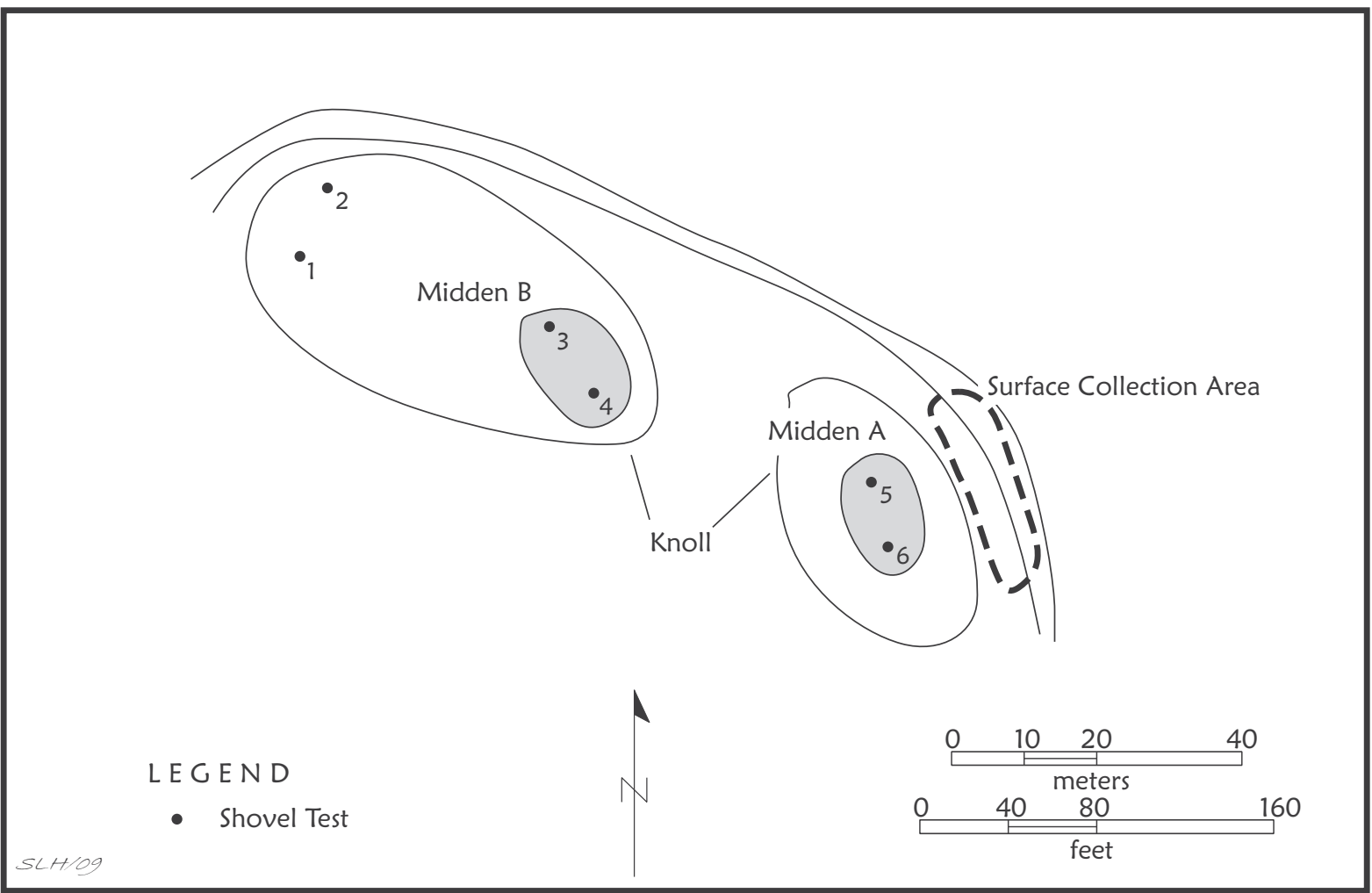

Figure 2. Map of 41SM169.

Table 1. Recovered archaeological materials from 41SM169.

\begin{tabular}{lcl}
\hline Archaeological materials & No. & Comments \\
\hline Decorated ceramic sherds & 4 & Includes one engraved bottle sherd \\
Plain ceramic body sherds & 30 & \\
Bifacial tool fragment & 1 & \\
Core & 1 & \\
Lithic debris & 12 & \\
Fire-cracked rock & 1 & \\
\hline \multicolumn{1}{c}{ Totals } & 49 & \\
\hline
\end{tabular}

Reservoir (Perttula 1986). It is situated on a prominent knoll overlooking the floodplain of the Sabine River (Figure 3) and covers an estimated 12,000 $\mathrm{m}^{2}$ (ca. 3 acres); the current channel of the river lies ca. $100 \mathrm{~m}$ north of 41SM170, and a tributary creek marks the eastern limits of the site. It is very likely that this site is the same as the Hawkins site (41SM144) recorded by Sam Whiteside (Mark Walters, 2009 personal communication) in the 1950s, and that the latter site was misplotted on Texas
Archeological Research Laboratory topographic quadrangle maps.

Prehistoric archaeological materials were abundant here in shovel testing, which identified three areas of midden deposits at 41SM170 (see Figure 3), and from a January 1986 surface collection (Table 2). Along the crest of the knoll, exposed in a dirt road, is a large area with burned clay and daub concentrations likely marking the location of a burned prehistoric Caddo house, just north of 


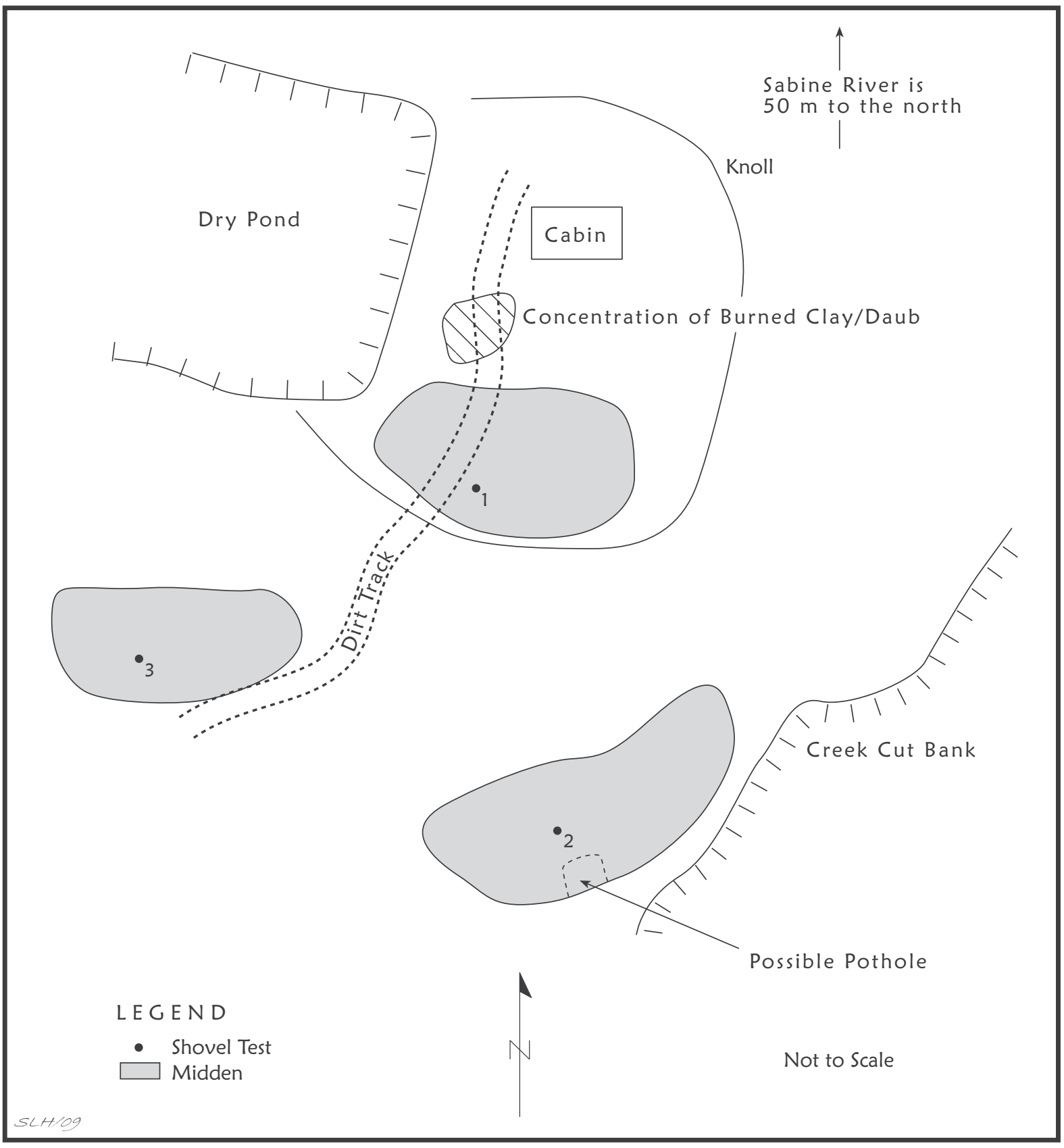

Figure 3. Map of 41SM170.

the northernmost midden on the site. The midden deposits, at least $35-45 \mathrm{~cm}$ in thickness, contained well-preserved mussel shell pieces (in ST 1 and ST 3 in two of the middens), animal bones (especially in ST 1), and ceramic vessel sherds.

In the surface collection from the dirt road that crosses the northern midden, plain $(n=23)$ and decorated ceramic sherds $(n=8)$ and animal bones are abundant (see Table 2). The plain to decorated sherd ratio is 2.88 . The decorated sherds include three fine ware body sherds from bottles and carinated bowls and five utility ware rim and body sherds. The sherds are tempered with grog $(75 \%)$ and grog-bone $(25 \%)$.

The engraved bottle sherds have narrow hatched zones and ladders (Figure 4a-b), decorative elements widely shared on Middle Caddo ceramics in parts of the upper Sabine River basin (Perttula and Cruse 1997:34). The carinated bowl sherd has a single fine 
Table 2. Recovered archaeological materials from 41SM170.

\begin{tabular}{lcl}
\hline Archaeological materials & No. & Comments \\
\hline Decorated ceramic sherds & 8 & Includes engraved bottle sherds \\
Plain ceramic rim sherds & 2 & \\
Plain body sherds & 19 & \\
Plain base sherds & 2 & \\
Animal bones & 19 & \\
Mussel shell fragments & + & \\
Charred nutshells & 3 & \\
Lithic debris & 2 & \\
\hline
\end{tabular}

\section{Totals}

55

$+=$ present

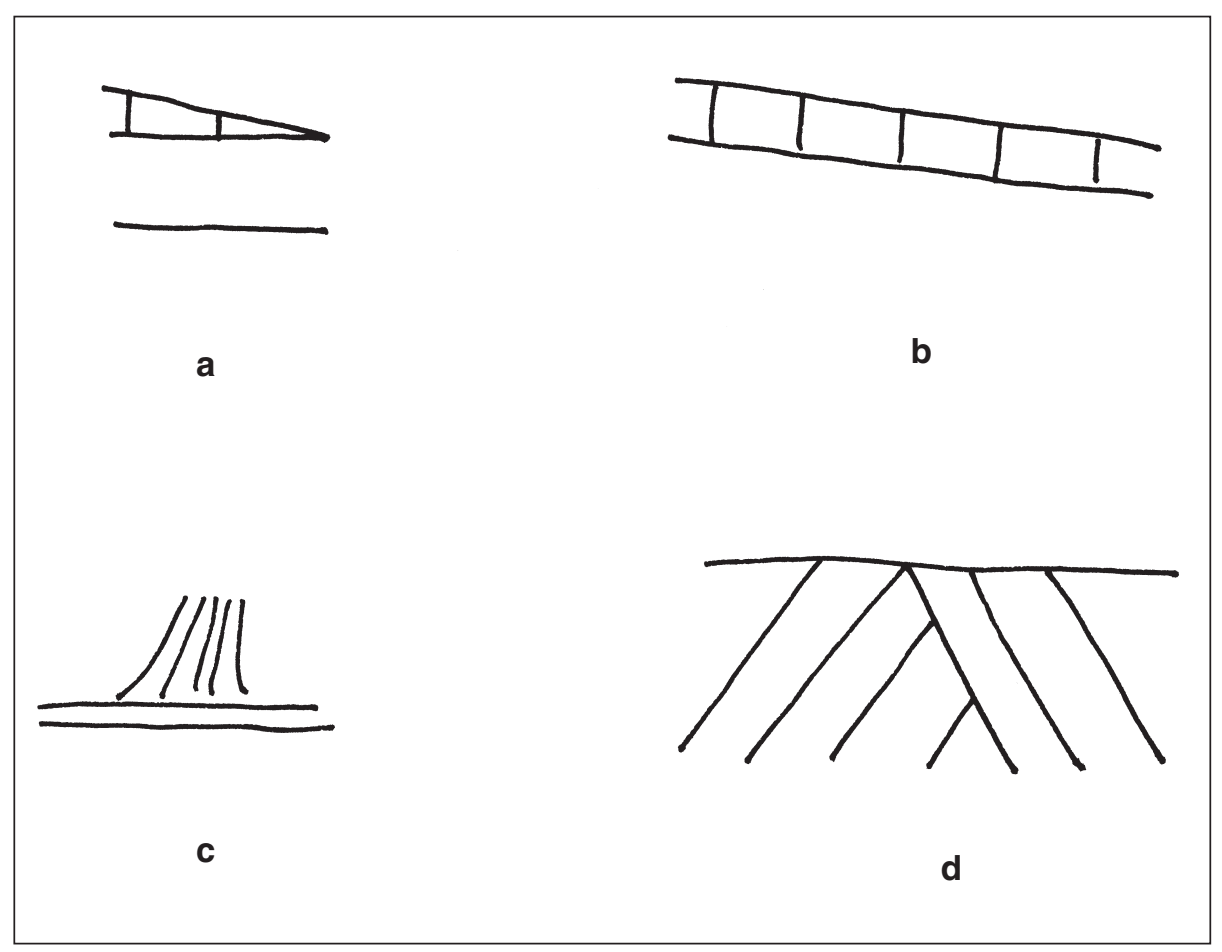

Figure 4. Selected decorative elements on sherds from 41SM170 and 41WD36: a-b, engraved bottle sherds from 41SM170; c, vertical engraved bracket element from the midden at 41WD36; d, opposed incised rim sherd from the midden at 41WD36.

diagonal engraved line on it.

The two utility ware rim sherds have rows of tool punctations on them. A body sherd has rows of fingernail punctations. Two other sherds have incised line decorations, including one with parallel incised lines and the other with only a single straight incised line. The two plain rims indicate that there are also plain vessels in the 41SM170 ceramic assemblage.

\section{WD36}

This site had first been recorded in 1971 by Malone (1972) during the archaeological survey of 
the proposed Carl Estes/Mineola Reservoir on the Sabine River, and a second time by James E. Bruseth in May 1976 (Bruseth 1976). The site is located on a large terrace, with several knolls or pimple mounds, overlooking the Sabine River floodplain and Cedar Lake (an old river channel) to the south, and Cottonwood Creek to the east. In 1976, one of the knolls had prehistoric Caddo sherds eroding out of it.

In 1977, Bob D. Skiles, then living in Mineola, found a trash midden on the edge of the landform at the site, just above a steep slope toward Cottonwood Creek; the midden was marked by darkly-stained soil and flecks of mussel shell in rodent back dirt piles. He excavated a single shovel test in the midden, which contained Caddo ceramic sherds, burned clay, animal bone, and mussel shell fragments. In January 1986, Timothy K. Perttula and Skiles returned to the site and excavated two additional shovel tests at 41WD36. They encountered midden deposits between $20-40 \mathrm{~cm}$ bs in one of the shovel tests (ST 2) (Table 3), and both shovel tests had ceramic sherds; ST 2 also had animal bone.

Only $8 \%$ of the 37 sherds recovered in the 1977 and 1986 shovel testing are decorated (see Table 3 ); this is a plain to decorated sherd ratio of 11.33. They include a carinated bowl sherd with horizontal engraved lines above the carination as well as a vertical engraved bracket element with multiple arcing lines (see Figure 4c); this decorative element is reminiscent of pre-A.D. 1400 Poynor Engraved motifs documented in the upper Neches River basin (Perttula 2009a). Another fine ware rim sherd has a single diagonal engraved line on it. The one decorated utility ware sherd is a grog-tempered rim with opposed sets of incised lines (see Figure 4d), either from a Canton Incised or Maydelle Incised jar.

\section{WD354, The Whooping Site}

The Whooping site is a Late Caddo period, Titus phase, habitation site with midden deposits; it is estimated to cover an area of more than 9 acres. It is situated on an upland landform overlooking the Caney Creek floodplain, and the upland landform is just above the normal flood pool of Lake Fork Reservoir, which lies to the immediate south of the site. Before the floodplain was inundated, there was a small natural lake (probably an old channel of Caney Creek) about $200 \mathrm{~m}$ south of the Whooping site.

Midden A appears to be a trash midden in the edge of a post-oak flat, a shallow swampy upland depression that becomes a shallow pond after every rain (Figure 5). In 1977, James E. Bruseth and Bob D. Skiles excavated a $1 \times 1 \mathrm{~m}$ unit in this midden; the archaeological materials recovered from this unit should be in curation at Southern Methodist University, but to my knowledge, no final publication of the analysis of these materials has been completed. The other three middens (Middens B-D) at the site are on slightly raised areas south of Midden A (Figure 5), and probably represent house locations, with Midden A representing the common trash area. A ca. 2 $\mathrm{m}$ diameter burned clay feature has been reported east of Midden C. It is also known that at least two prehistoric Titus phase Caddo burials have been excavated at the site by Mr. J. A. Walters in the 1960s (see Perttula et al. 2009).

Table 3. Recovered archaeological materials from 41WD36.

\begin{tabular}{lcl}
\hline Archaeological materials & No. & Comments \\
\hline Decorated ceramic sherds & 3 & Includes engraved carinated bowl sherds \\
Plain rim sherd & 1 & \\
Plain body sherds & 31 & \\
Plain base sherds & 2 & \\
Burned clay & 4 & \\
Animal bone & 6 & \\
Mussel shell fragments & + & \\
\hline Totals & 47 & \\
\hline
\end{tabular}




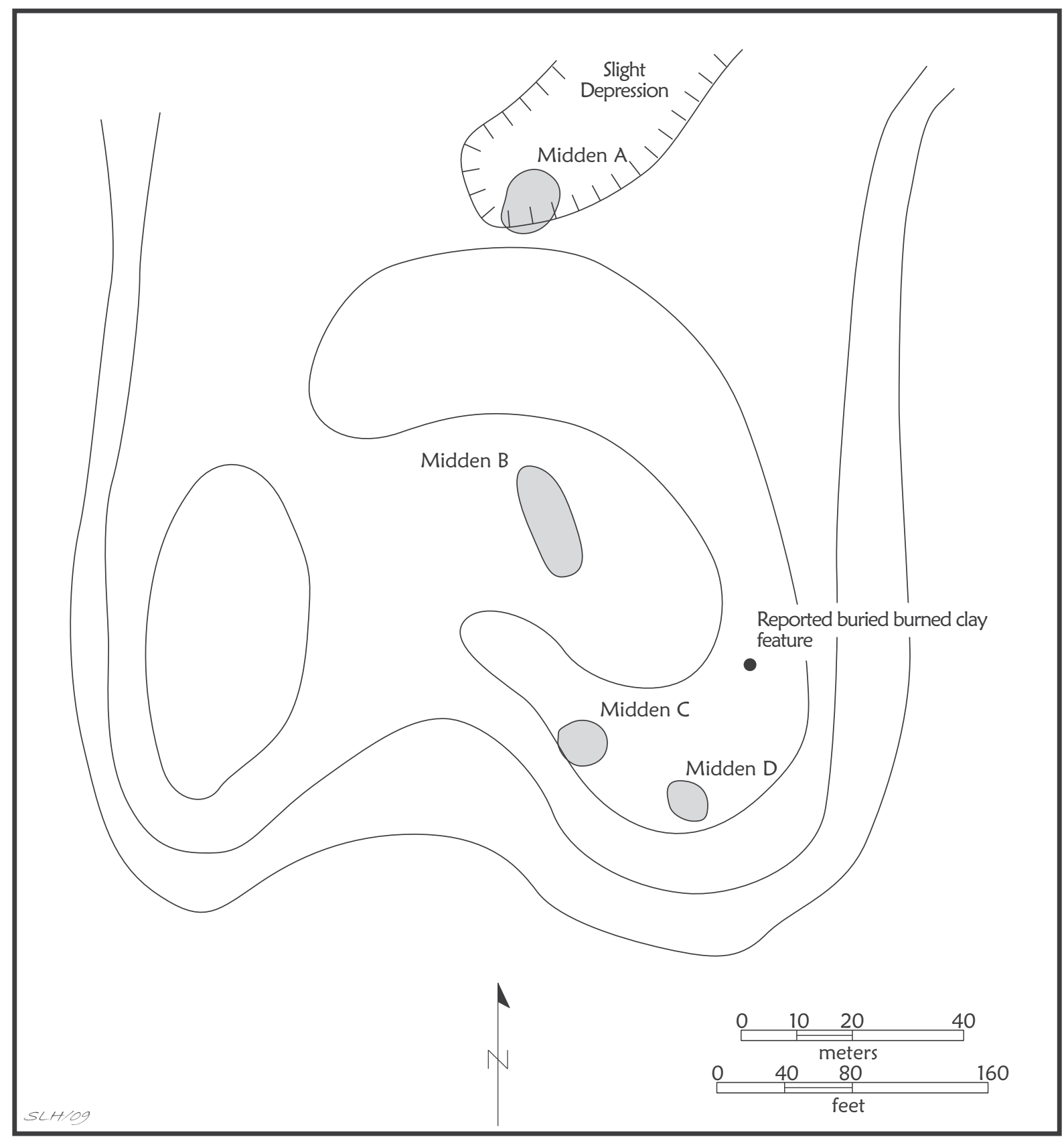

Figure 5. Map of the Whooping site (41WD354).

In May 1986, Perttula and Skiles returned to the site to excavate two shovel tests. One (ST 2) was placed in Midden A, and encountered dark charcoalstained midden deposits and ash lens to $47 \mathrm{~cm}$ bs. The few limited notes are silent, unfortunately, on the location of ST 1, other than that it was placed in one of the other middens at the Whooping site, and extended to $35 \mathrm{~cm}$ bs. The shovel tests recovered an abundance of ceramic sherds ( $\mathrm{n}=115)$, mussel shell fragments, as well as a few pieces of burned clay and animal bones. A single novaculite drill blade fragment was collected from $35-47 \mathrm{~cm}$ bs in ST 2 (Table 4).

The 115 sherds include 16 decorated fine ware and utility ware sherds and 99 plain rim, body, and base sherds (see Table 4). The plain to decorated sherd ratio is 6.19 , which is consistent with other Titus phase sites in the Caney Creek locality in the 
Table 4. Recovered archaeological materials from the Whooping site (41WD354).

\begin{tabular}{lcl}
\hline Archaeological materials & No. & Comments \\
\hline Decorated ceramic sherds & 16 & Includes red-slipped sherds \\
Plain rim sherd & 4 & \\
Plain body sherd & 90 & \\
Plain base sherd & 5 & Made of novaculite \\
Burned clay & 2 & \\
Chipped drill & 1 & \\
Animal bones & 2 & \\
Mussel shell fragments & + & \\
\hline Totals & 120 & \\
\hline
\end{tabular}

$+=$ present

upper Sabine River basin (Perttula 2009b:Figure 62 and Table 26). Seven of the decorated sherds are from fine wares, among them two red-slipped carinated bowl sherds and five sherds with engraved or excised lines and no discernible decorative elements/ motifs, but most probably from Ripley Engraved carinated bowls given a horizontal engraved line under the lip on one rim and two other sherds with excised curvilinear engraved lines. One carinated bowl rim, red-slipped on both interior and exterior surfaces, has diagonal engraved lines on it.

The utility ware sherds include corn cob impressed $(n=1)$, brushed $(n=2)$, neck banded $(n=1)$, appliqued $(n=3)$, and incised $(n=2)$ decorations, a range of decorations that are consistent with the Titus phase affiliation of the site. The corn cob impressed sherd is from an Anglin Impressed jar (cf. Perttula 2009b:34). The brushed sherds are body sherds with parallel (probably vertical) brushing marks, and the neck banded sherd is from a La Rue Neck Banded cooking jar. The appliqued sherds include two body sherds with straight appliqued ridges (McKinney Appliqued?), and a rim with an appliqued lug handle. One of the incised sherds is a Maydelle Incised rim with cross-hatched incised lines; the other is a body sherd with parallel incised lines.

\section{WD507, CXA Site}

The CXA site is a probable Middle Caddo period (ca. A.D. 1200-1400) household trash midden recorded by Bob D. Skiles. It is situated on an upland ridge toe slope that projects into the Alum
Branch floodplain, approximately $0.5 \mathrm{~km}$ west of the confluence of Alum Branch and Lake Fork Creek; Lake Fork Creek is one of the principal tributaries of the Sabine River in the upper Sabine River basin. The overall size of the site is unknown.

Bob Turbeville excavated the central part of this $20 \mathrm{~m}$ diameter midden in 1971, and then in $1977 \mathrm{Jim}$ Bruseth and Skiles excavated a $1 \times 1 \mathrm{~m}$ unit into an unexcavated part of the midden. The bone preservation was "exceptionally good; Bob [Turbeville] recovered several dozen antler tools, and a bunch of Sanders Plain... I remember one small (miniature) Sanders Plain carinated bowl he showed me from the midden (the only intact vessel). There is abundant charcoal" (Bob D. Skiles, 2009 personal communication). A level, slightly more elevated spot near the trash midden deposits is probably the location of an associated Middle Caddo house place; according to Skiles (2009 personal communication), "the sandy loam is quite shallow here over the B-horizon (so at least one could expect a good post hole pattern and the bottoms of the pit features to be preserved)."

The recovered archaeological materials are from general contexts at the CXA site (Table 5), presumably surface collections, except for the animal bones. The animal bones came from a single shovel test and the Unit 1 plow zone $(0-20 \mathrm{~cm}$ bs). The analysis of the remainder of the archaeological materials from the 1977 excavation of Unit 1 has not been completed, and the location of these materials is not presently known.

Other than animal bones, the collection of prehistoric artifacts from the CXA site is dominated by 
Table 5. Recovered archaeological materials from the CXA site (41WD507).

\begin{tabular}{lcl}
\hline Archaeological materials & No. & Comments \\
\hline Decorated ceramic sherds & 30 & $\begin{array}{c}\text { Includes red-slipped sherds and engraved } \\
\text { bottle sherds }\end{array}$ \\
Plain rim sherds & 3 & \\
Plain body sherds & 106 & \\
Plain base sherds & 3 & Gary point \\
Burned clay & 16 & \\
Dart point & 1 & \\
Lithic debris & 9 & \\
Animal bones & 67 & \\
Mussel shell fragments & + & \\
\hline \multicolumn{1}{c}{ Totals } & 235 & \\
\hline
\end{tabular}

$+=$ present

plain and decorated ceramic sherds $(n=142)$, with small amounts of burned clay $(\mathrm{n}=16)$, and lithic debris (see Table 5). Almost $90 \%$ of the lithic debris is from local quartzite and petrified wood sources.

The plain to decorated sherd ratio for the CXA site ceramic assemblage is 3.73 . The fine wares $(57 \%)$ dominate the decorated sherds. Eight of the fine ware sherds are body sherds from red-slipped bottles. The remainder of the fine ware sherds are engraved $(n=9)$, including a rim with parallel vertical to curved lines (Figure 6a; Walters [2009:Figure 6h-i] illustrates similar sherds from the Henry Chapman site on Prairie Creek in the upper Sabine River basin); a cross-hatched engraved rim (Sanders Engraved) and two cross-hatched body sherds (including one with a red pigment rubbed in the engraved lines); a diagonal engraved rim (Sanders Engraved); a body sherd with parallel engraved lines; and a body sherd with an engraved triangle element (Figure $6 \mathrm{~d}$ ). The two bottle sherds have a cross-hatched triangular engraved element (Figure $6 \mathrm{~b}$ ) and a large hatched triangular element (Figure 6c).

The utility ware sherds are from vessels decorated with incised $(n=10)$, incised-punctated $(n=1)$, punctated $(n=1)$, and brushed $(n=1)$ elements; the brushed body sherd has parallel brushing marks. Among the incised sherds (Canton or Maydelle Incised) are four rim or body sherds with opposed incised lines (see Figure 6e); three rim and body sherds with diagonal incised lines; a cross-hatched incised rim (see Figure 6f) and body sherd; and a body sherd with a single straight incised line on it. The incised-punctated sherd has a zone of cane punctations adjacent to a single straight incised line; the punctated zone is probably triangular-shaped. Finally, the one punctated body sherd has randomly placed small circular punctations that cover the vessel exterior surface.

\section{Analysis of Faunal Remains from 41WD507, LeeAnna Schniebs}

Investigations at a probable Middle Caddo midden (41WD507) on the Sabine River in Wood County, Texas, yielded 67 bone fragments, with a total weight of 85.9 grams. They were recovered from a single shovel test $(n=13)$ and from $0-20 \mathrm{~cm}$ bs $(\mathrm{n}=54)$ in one excavation unit. Approximately 54\% of the sample is identifiable to the lowest taxonomic level possible (e.g., family, genus, or species). All classes of vertebrates are represented, but unidentifiable large mammal is dominant; these are most likely the remains of deer. Table 6 presents number of identifiable specimens, minimum number of individuals, their preferred habitat, and percent of the sample.

Standard zooarchaeological identification techniques were employed in this analysis, using comparative skeletal collections. Attributes of the identifiable bones include taxon, element and portion of that element, symmetry, age if possible, burning, and weight. Weights of specimens and burning were also recorded (information on file, Archeological \& 


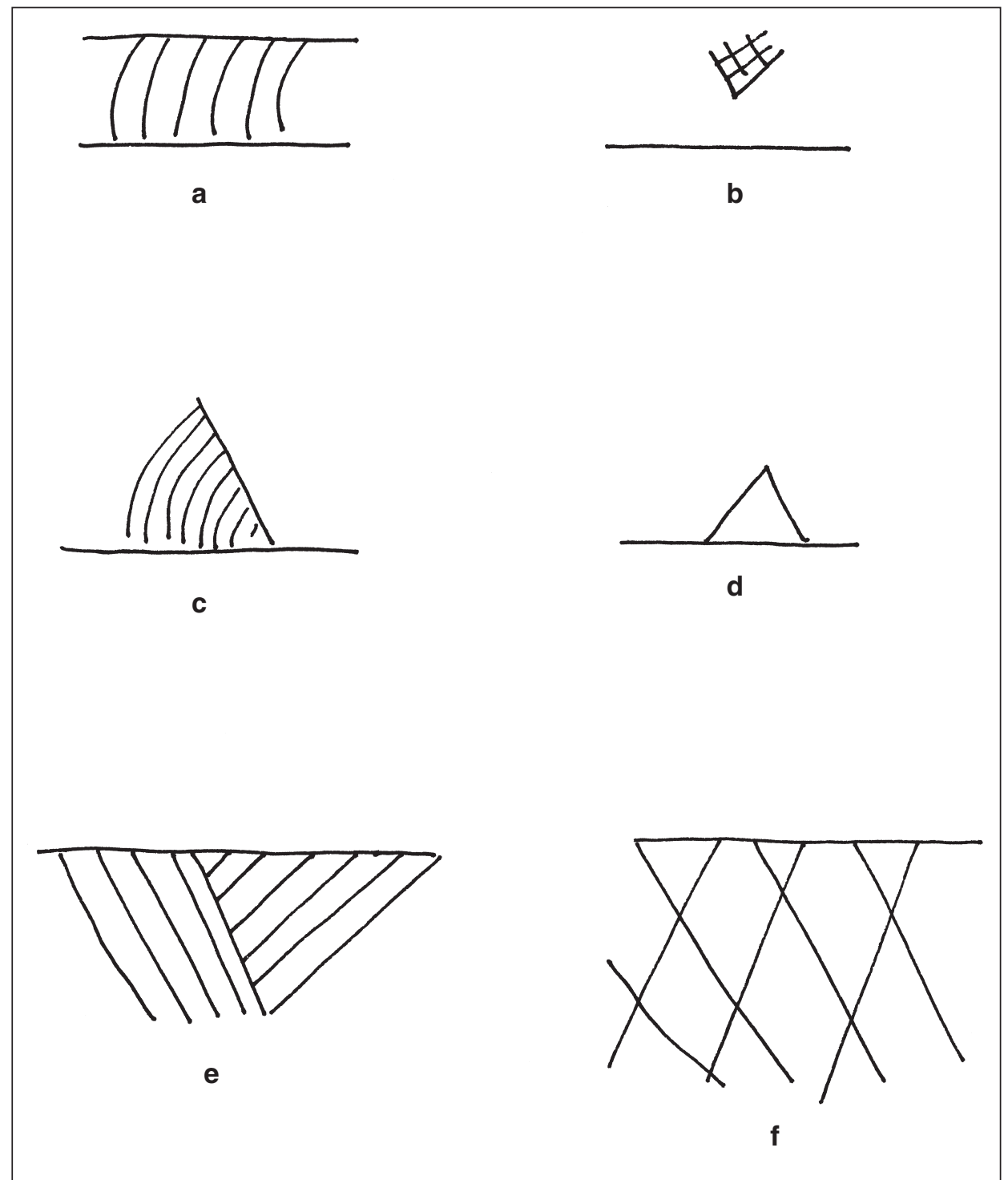

Figure 6. Selected decorative elements on decorated sherds from the CXA site: a, parallel vertical to curvilinear engraved rim; b, cross-hatched engraved element, bottle; $c$, hatched engraved triangular element, bottle; d, triangular engraved element; e, opposed incised rim sherd; f, cross-hatched incised rim sherd.

Environmental Consultants, LLC, Austin, Texas). The analysis presented herein is concerned with identifying broad trends in subsistence and animal exploitation of the Middle Caddo population at this specific site in the East Texas Pineywoods.

Although the 41WD507 faunal sample is small in quantity, it provides a general overview of the area's available animal resources and the dietary preferences of the Caddo in prehistoric times. Aquatic species (fish, bullfrog, and pond turtle) were easy to obtain as the site was located near the Sabine River, but they were probably just supplemental foods. The wooded edges provided habitat for the cottontail, turkey, and deer. The woodlands and bottomlands were hunted for the box turtle, squirrel, and swamp rabbit. The animals identified suggest occupation during warmer months.

White-tailed deer is undoubtedly the main meat source of the Caddo diet. The approximate edible meat weight of a single deer is about 35 pounds (White 1953). It is possible that more than one individual is actually represented in the small sample at 41WD507, as MNI estimates are usually numerically conservative. 
Table 6. Summary of Taxonomic Recovery from 41WD507.

\begin{tabular}{|c|c|c|c|c|}
\hline Taxon & NISP & MNI & Habitat* & $\begin{array}{l}\text { Percent of } \\
\text { Sample }\end{array}$ \\
\hline Vertebrata (indeterminate) & 1 & - & - & 1.49 \\
\hline Indeterminate fish (Osteichthyes) & 1 & 1 & A & 1.49 \\
\hline Bullfrog (Rana catesbeiana) & 1 & 1 & A & 1.49 \\
\hline Pond slider turtle (Pseudemys sp.) & 1 & 1 & A & 1.49 \\
\hline Box turtle (Terrapene sp.) & 1 & 1 & $\mathrm{~W}, \mathrm{~B}$ & 1.49 \\
\hline Indeterminate turtle (Testudinata) & 9 & - & - & 13.44 \\
\hline Turkey (Meleagris gallopavo) & 2 & 1 & WE & 2.98 \\
\hline Cottontail or swamp rabbit (Sylvilagus sp.) & 6 & 1 & WE or B & 8.96 \\
\hline Squirrel (Sciurus sp.) & 1 & 1 & $\mathrm{~B}, \mathrm{~W}$ & 1.49 \\
\hline \multicolumn{5}{|l|}{ White-tailed deer } \\
\hline (Odocoileus virginianus) & 14 & 1 & WE & 20.90 \\
\hline Mammal (large Mammalia) & 30 & - & 44.78 & \\
\hline Total & 67 & 8 & & 100 \\
\hline
\end{tabular}

NISP=number of identifiable specimens; MNI=minimum number of individuals; * Preferred Habitat (Davis 1978; Schmidly 1983): A=aquatic (rivers, swamps, marshes); B=bottomlands (riparian habitats); W=woodlands (deciduous or pine forests); WE=wooded edges (open meadows, parkland)

The faunal sample demonstrates that hunting activities played a role in the diet of the Middle Caddo peoples that lived at this site. Previous investigations at other Caddo sites in the general area have identified similar animal resource utilization patterns as well as comparable species composition of procured animals (see Yates 1999; Schniebs 2008; Walters 2008:80-103). Environmental areas exploited by Caddo hunters include aquatic and riparian habitats, forests, and open meadows with wooded edges

\section{CONCLUSIONS}

These five prehistoric Caddo sites in the Upper Sabine River basin of Northeast Texas run the gamut from pre-A.D. 1200 habitation sites to Late Caddo (ca. A.D. 1400-1680) settlements, with attendant differences in the character of their ceramic sherd assemblages (the most common kind of artifact found on the sites). From the available information, these prehistoric Caddo sites were each occupied during specific, and probably short-term, spans of time (each probably less than 50-100 years) during the lengthy Caddo settlement of the region, and they contain domestic features, primarily midden deposits. These midden deposits represent areas of concentrated trash disposal, and may also mark the locations of abandoned Caddo house structures.

Further investigations at these sites is likely to obtain significant information on the domestic character of different Caddo groups that occupied the region. This would certainly include archaeological data on the kinds of domestic structures that were constructed at the sites and how long the sites and the structures were occupied, the location and nature of preserved extra-mural features (such as trash middens, storage pits, outdoor activity areas, granaries, and cemeteries), as well as the diversity of ceramic and lithic material culture remains on each of the sites. Are the ceramic assemblages sufficiently distinctive through time and across space that particular ceramic traditions can be defined in the Upper Sabine River basin? Perhaps most importantly, the existence of well preserved midden deposits with preserved animal bones and (likely) charred plant remains at the five sites strongly suggests that direct evidence for the subsistence pursuits of these local Caddo groups can be obtained through further archaeological investigations, and we can quantify the importance of domesticated plants, wild plant 
foods, and game animals in the local prehistoric Caddo diets.

\section{ACKNOWLEDGEMENTS}

I would like to thank Bob D. Skiles and Mark Walters for sharing recollections about several of the sites discussed in this article. Sandra Hannum prepared the figures used herein.

\section{REFERENCES CITED}

Bruseth, J. E.

1976 Archaeological Reconnaissance of an FEA Pipeline. Research Report No. 86. Archaeology Research Program, Southern Methodist University, Dallas.

Davis, W. B.

1978 The Mammals of Texas. Bulletin No. 41, revised. Texas Parks and Wildlife Department, Austin.

Malone, J.

1972 Archaeological Reconnaissance at proposed Mineola Reservoir. Archeological Survey Report 10. Texas Historical Survey Committee and Texas Water Department Board, Austin.

Perttula, T. K.

1986 Archeological Reconnaissance in the Waters Bluff and Upper Little Cypress Reservoirs, Gregg, Harrison, Smith, Upshur, and Wood Counties, Texas. Submitted to the Bureau of Reclamation, Southwest Region, by Prewitt and Associates, Inc., Austin.

1995 Collected Papers on Caddoan Archaeology in the Upper Sabine River Basin, Northeastern Texas. Special Publication No. 1. Friends of Northeast Texas Archaeology, Austin and Pittsburg.

2009a The Ceramic Artifacts from the Lang Pasture Site (41AN38) and the Place of the Site within an Upper Neches River Basin Caddo Ceramic Tradition. In Archeological Investigations at the Lang Pasture Site (41AN38) in the Upper Neches River Basin of East Texas, edited by T. K. Perttula and D. B. Kelley, pp. 6-1 to 6-260. MS on file, Texas Department of Transportation, Archeological Studies Program, and prepared by Archeological \& Environmental Consultants, LLC, Austin, and Coastal Environments, Inc., Baton Rouge.
Perttula, T. K., with contributions by E. Dowd, L. Green, G. Morgan, B. Nelson, L. Schniebs, B. Schriever, J. Todd, and $\mathrm{M}$. Walters

2009b The Archaeology of the $16^{\text {th }}$ and $17^{\text {th }}$ Century Caddo in the Post Oak Savannah of Northeast Texas: The Tuinier Farm (41HP237), R. A. Watkins (41HP238), and Anglin (41HP240) Sites in the Stouts Creek Basin, Hopkins County, Texas. Journal of Northeast Texas Archaeology 30:1-132.

Perttula, T. K. and J. B. Cruse

1997 The Caddoan Archaeology of the Sabine River Basin during the Middle Caddoan Period. Journal of Northeast Texas Archaeology 9:30-37.

Perttula, T. K., M. Walters, S. Marceaux, and B. Nelson

2009 Caddo Pottery Vessels and Pipes from Sites in the Middle and Upper Sabine and Upper Neches River Basins, Smith and Wood Counties, Texas. Special Publication No. 7. Friends of Northeast Texas Archaeology, Austin and Pittsburg.

Schmidly, D. J.

1983 Texas Mammals East of the Balcones Fault Zone. Texas A\&M University Press, College Station.

Schniebs, L.

2008 Faunal Analysis. In Lake Naconiche Archaeology, Nacogdoches County, Texas: Results of the Data Recovery Excavations at Five Prehistoric Archeological Sites, Vol. II, edited by T. K. Perttula, pp. 581610. Report of Investigations No. 60. Archeological \& Environmental Consultants, LLC, Austin.

Walters, M.

2008 Life on Jackson Creek, Smith County, Texas: Archeological Investigations of a $14^{\text {th }}$ Century Caddo Domicile at the Leaning Rock Site (41SM325). Caddo Archeology Journal 17:1-114.

2009 The Henry Chapman Site (41SM56). Journal of Northeast Texas Archaeology 31:11-35. 